Медіафорум : аналітика, прогнози, інформаційний менеджмент : зб. наук. праць. - Чернівці :

Чернівецький нац. ун-т, 2020. -

Том 8. - C. 115-131
Mediarorum: Analytics, Forecasts, Information Management: Collection of Research Articles. - Chernivtsi: Chernivtsi National University, 2020. Vol. 8. - pp. 115-131

https://doi.org/10.31861/mediaforum.2020.8.115-131

УДК: $323.21(4+477)$

(C) Mykola Luchak

(C) Anna-Maria Luchak-Fokshei

\title{
MORAL AND POLITICAL CRISIS OF INTERSUBJECTIVITY IN EUROPE AND UKRAINE: IMPLEMENTATION OF DELIBERATIVE DEMOCRACY IDEA
}

The article explores formation of new ideals and values that has become a key task of the European community after overcoming totalitarianism. Many researchers of that time were looking for methods to prevent atomization and establish democracy, and one of the methods was communicative philosophy. This approach helped to shape the main narratives that still shape the politics of Western Europe. However, Brexit, the international economic crisis of 2008-2011, the COVID-19 pandemic are Black Swans that each time set the tone for the mood of society and determine the meanings of narratives on social networks (virtual and real).

The communicative-network transformation of society is capable of materializing the discourse around new problems of the world in order to prevent a moral split. The virtual dimension of our everyday life acquires key roles in the dissemination of thoughts and shaping the mood of society. This transformation creates new threats to liberal values that were formed long before the "state in the smartphone". Focusing attention on the modern conditions of human life will help to better understand its political behavior and ways to create better conditions for democracy in modern society.

Key words: virtualization, digitalization, intersubjectivity, deliberative democracy, communicative-network transformation.

1 Кандидат філологічних наук, доцент кафедри сучасних іноземних мов та перекладу Чернівецького національного університету імен Юрія Федьковича, Україна. E-mail: m.luchak@chnu.edu.ua.

${ }^{2}$ Кандидат філософських наук, бренд-менеджер, IT-компанія SoftServe. E-mail: am.fokshei@gmail.com. 


\section{Моральна та політична кризи інтерсуб'єктивності в Європі та Україні: імплементація ідеї деліберативної демократії}

Формування нових ідеалів та изіностей стало ключовим завданням європейської спільноти після подолання тоталітаризму. Чимало тогочасних дослідників шукали методи для попередження атомізаціі та утвердження демократії, одним з яких стала комунікативна білософія. Цей підхід допоміг сформувати головні наративи, які до иих пір визначають політику Західної Європи. Однак історія не розивається лінійно, а чимало соціальних процесів розгортаються завдяки, на перший погляд, непомітними зв'язками. Brехіт, Міжнародна економічна криза 2008-2011 років, пандемія COVID-19 - це «чорні лебеді», які щоразу задають тон настроїв суспільства та визначають смисли наративів у соціальних мережах (віртуальних та реальних).

Комунікативно-мережева трансформачія суспільства здатна матеріалізувати дискурси довкола нових проблем світу заради попередження морального розколу. Віртуальний вимір нашого буденного життя набуває ключової ролі в почиренні думок та формуванні настроїв суспільства. Без використання критичного мислення, ми ризикуємо втратити ращіональність як основу наших дій $і$ назавжди залишитися під владою ірраціональних мотивів, фейків та ботів. На основі політичній теорії Ю. Габермаса проаналізовано актуальний стан політичного дискурсу, а також потениійний вплив повної або часткової імплементації делібаритивної демократії.

Електронне врядування - $є$ одним з фундаментальних понять інформаційного суспільства. Завдяки посиленій диджиталізацї (поштовхом для якої з 2020 став lockdown), чимало бюрократичних процесів зараз активно переносяться у віртуальний вимір, аразом зиим змінюється парадигма відносин «людина-держава». Ця трансбормація створює нові загрози для ліберальних иінностей, які формувалися задовго до «держави у смартфоні». Facebook, Google, Amazon ma чимало інших Інтернет-гігантів володіють алгоритмами, які здатні не тільки збирати дані, але й використовувати іх для стимулювання бажаної поведінки користувачів та споживачів. Зосередження уваги на сучасних умовах життя тюдини допоможе краще зрозуміти ї політичну поведінку та шляхи формування найкращих умов для демократіі у сучасному суспільстві. 
Ключові слова: віртуалізація, диджиталізація, інтерсуб'єктивність, деліберативна демократія, комунікативно-мережева трансформачія.

Problem statement. After overcoming totalitarianism, the European community faced the need to update the discourse around new ideals and values that could overcome the threat of atomization and consolidate society on the foundations of democracy. The response to these challenges was communicative philosophy, the main task of which is to find ways to achieve mutual understanding through rethinking the ethical foundations of speech intersubjective interaction. To do this, it was necessary to create narratives and discourses that would introduce new concepts and meanings into our speech existence - the basis of a future democratic world free from violence. To achieve this goal, numerous multinational associations were formed, proclaiming the common good as a priority over the private interests of each of the member states. This area of openness offered new structures for implementing the main principles of liberalism, which stimulated the development of civil society and created a standard for young democracies in Eastern Europe.

However, Black Swans (unpredictable and irregular events of a huge scale that have serious consequences (Taleb, 2016)) regularly test these new structures for strength and ideological stability. The fall of banks and the international economic crisis of 2008-2011 destroyed the middle class and social stratification (according to scientists) in many countries. Today we are experiencing a crisis of democracy along with a moral and ethical crisis. The latter has been caused not so much by the loss of the semantic load of the concept of power and democracy itself, but by the lack of readiness of humanity for a new era. By inertia, like our predecessors, we build reliability, even though the modern world is already so saturated with the discourses and narratives that exist in them that these systems develop themselves as living organisms. Verbalized in natural and artificial languages, they are rooted in our perception of reality in every possible way. A modern man, instead, refuses to understand complexity and non-linearity and resorts to procrastination.

We are taken by the Black Swans from Naseem Taleb's theory from this amorphous state. Thus, Brexit (the UK's exit from the EU in June 2016) has shown how different the value principles of countries in the Commonwealth might be. This turn has changed the image of the European 
community from a single one to rather fragmented inside. This problem does not start with foreign policy; it is born in the mood of society itself. Forced multiculturalism stimulated the revival of the flow of immigrants from disadvantaged countries in the Middle East, as well as the provision of an advantage in social guarantees to refugees, and not to citizens of the state. Unfortunately, differences in religious and cultural worldviews have destroyed artificially created communication channels, which, in turn, led to a change in the structures of the sphere of openness. Jurgen Habermas observed "a sharp increase in social inequality and a sense of powerlessness when your own interests are no longer represented at the political level - this forms the basis for mobilization against foreigners, against Europe and hatred of Brussels" (Habermas, 1984).

Communication and network transformation can materialize discourses around new problems of the European community in order to avoid a split in society. In fact, it is currently happening, but it is not properly understood. This subject of research is divided into small pieces by 118 different branches and is not understood as a single whole. Communica-

- tion networks are an abstract concept. After all, the subject of research (social networks and social capital) is objectively existing processes and systems. However, the communication network cannot be materialized, because fragmented discourses are scattered throughout the network in various forms. Due to front-end developers, users see blue-and-white designs, comment hierarchies, and message stickers - simulacra that adapt the virtual to human perception. For a software developer, virtuality is a set of code, but the philosopher will see a complex interweaving of artificial and natural languages, where the former one exists to implement the latter one. Only narratives help users combine these discourses into a single whole - a network.

A convincing argument in favor of this message is the Ukrainian Revolution of Dignity, during which solidarity was mainly carried out by involving citizens in a single Internet discourse on Facebook. This area of communicative openness allowed users to freely problematize their own judgments, respond to the opinions and statements of others, which, based on the social capital of active participants of the discourse, formed structures for forming narratives of freedom and respect for human dignity. Thus, Facebook can become a platform for the validation of humanistic ideas in the global network society. 
The era of the information society has created a medium that has become a new dimension of being - the Internet. Over time, this product of our intellectual activity, social evolution from secondary turned into primary: today it is a virtuality that determines reality where there are technical possibilities for this. As A. Karas noted, our perception of being is mediated by the semiotic-symbolic sphere (Karas, 2016, 13-28). Social networks were created in response to the increasing complexity of the world and the intersubjective connections in it. That is why a social network is a verbally modeled human reality, which is a virtual reflection of our daily interpersonal interactions. The first and, in our opinion, until now the only fundamental function of the network is not the dissemination of information, but the accumulation of social capital.

Communicative and interactive tendencies have created favorable conditions in which many discourses of the present are not only duplicated in social media communication but also emerge, develop and shape new narratives in cyberspace. This opened up the opportunity for democracy to become truly horizontal, where government officials do not act as independent units, but productively interact with citizens to improve the existing system of norms and values, economic and social spheres (Luchak, 2016, 147-149).

The Declaration on Building the Information Society as the Global Challenge of the New Millennium (2005) states that "information and communication technologies should be used as an important tool for good governance" (Declaration of Principles). Over the past decade, this idea has been implemented in the legislation of many countries. In particular, in the USA, during Barack Obama's tenure, a real mechanism of interaction between all branches of government and active citizens was created precisely through social media communication. In Ukraine, an electronic city management system was proposed, which, although was not as interactive as its counterparts in the UK, but high-performance indicators open up the prospect of actively attracting public activists (e-activism).

Recent research and publications analysis. The discourse around the issue of electronic governance and its relevance today is filled with the searches of many Ukrainian political scientists and economists (Ya. Meril, V. Eyganov, L. Levchenko, A. Tkachenko and others). The issue remains open for philosophy, whether democracy in this dimension will not lose the human face and social values and norms will be preserved, and which ones can be lost. 
Study objectives. The purpose of the article is to carry out a general analysis of the communication-network transformation of society, as well as its potential impact on moral and political discourses.

Results and discussion. The formation of a global information society begins with local transformations. Internet communities formed due to their making common cause around common ideas, views, or to achieve certain goals, create a single platform where a more or less rational formation of public opinion and political will, can take place (Masuda, 1993, 3650). In this context, the issue of transformation of the form of management is actualized. I. Masuda in his work Computopia notes that in contrast to an industrial society with a parliamentary system and majority rule, a characteristic feature of the information society is the policy of autonomous management of citizens on the principle of synergy and attention to the opinion of the minority. That is, in the information society, the political system will become participatory democracy.

However, the implementation of this approach is impossible neither within the republican nor liberal view of governance. Participatory democracy means intersubjective interaction of citizens in the discourse of power (Luchak, 2015, 62-65). "The discourse theory solves very important unresolved issues of understanding not only the transition to democracy, but also to autocracy and authoritarianism, as well as electoral and other forms of democratic participation" (Anderson, 2003). The interpretation of the discourse by the American political philosopher Richard Anderson is the best fit for the social networking pragmatism of the democracy formation. The philosopher explains political discourse as "the procedures for organizing composition and interpreting texts disseminated by individuals, who carry out political conversations" (Anderson, 2003). Politicians disseminate these texts through press releases, their own public pages on social networks, and thus the interpretation of these texts generates new discourses and narratives.

According to J. Habermas, deliberative democracy is the only one that can legitimize such a discourse. The consequence of the unofficial formation of public opinion is institutionalization in the form of a choice of decisions and in legislative regulations, thanks to which power is communicatively created and transformed into power, which is applied in an administrative way (Habermas, 2001, 396). Thus, according to Article 5 of the Constitution of Ukraine, "the bearer of sovereignty and the only source of power in Ukraine is the people. The people exercise power directly 
and through state government bodies and local government bodies." The mechanisms for exercising the democracy "directly" are elections, referendums, demonstrations, etc. In this case, for example, elections, as noted by J. Habermas, play the role of a "license" for the implementation of a certain political program and oppose the authorities and civil society. The discursive concept of democracy, on the contrary, corresponds to the image of a decentralized society, which, however, shares with the political community the arena of perception, identification and development of problems concerning the entire society (Habermas, 2001, 399). If we change the approach to the phenomenon of sovereignty from subjectivity to intersubjective, then it does not need either concentration in the nation, or expulsion into the anonymity of constitutional and legal powers. The Self of the legal community is organized independently, turns into impersonal network connections that regulate the course of the discursive formation of public opinion and political will. However, popular sovereignty, which, although it has become anonymous, is separated in democratic procedures and in the legal implementation of their demanding communication conditions only in order to demonstrate itself as a communicatively established power.

Still, democracy as a form of government and the embodiment of liberal values has faced numerous challenges that threaten to undermine efforts to assert freedoms and human rights. The Freedom House, which monitors these processes, demonstrates in its research the qualitative and quantitative indicators of the democracy decline. Particular attention is paid to the cradle of liberal values - the United States and Europe, which in recent years, under the influence of the collapse of the idea of multiculturalism, have been more focused on their internal problems than on their own role of authority for young democracies. Ukraine, which has demonstrated three times over the past 25 years a "strong civic spirit" (according to A. de Tocqueville), has a chance to become an example of a new democracy where liberal values are discovered and affirmed through a discourse to which all members of civil society can join it.

However, weak social capital (one based on distant connections between people) and its passivity can become an obstacle in the future, which Francis Fukuyama spoke about at an open lecture in Lviv: "You have a civil society that has a powerful voice. There are potential leaders who represent it. We must also remember that Ukraine is a country with many educated people. Ukraine also has institutions that have enormous latent potential and the ability to change. You must not only confront the bad govern- 
ment but also go to power in order to change state institutions" (Fukuyama, 2020). However, in order for the government to undergo changes in society, values that will be shared by the majority of its members must be approved. The lack of mutual trust between citizens and trust in social institutions does not make it possible to create a general concept of the life world containing fundamental meanings obtained as a result of intersubjective interaction for the sake of establishing common social values. Ukraine as a state has gone through many crisis periods. Today, at a time of great global changes, internal reforms and the struggle for recognition in foreign policy, the Ukrainian nation is forming "antifragility" (according to N. Taleb)

Fundamental values should be united and disseminated by the only legitimate Ukrainian grand narrative, which can be partially formed on social networks. However, as noted by O.M. Horenko, to form it in a situation of linguistic, ideological and worldview split is a utopia (Horenko, 2020). Today in the world there are many techniques for the artificial formation of such stories, but their product is not enduring for the distant prospect of an active process of the nation. The grand-narrative implanted from the outside is perceived only by individual communities and does not penetrate beyond the level of everyday communication. Its values are ghostly and empathic. Of course, its ideas can be shared by a fairly large number of social groups, but this will be relevant until the flow of information changes and other, more relevant ideas take the place of the grand narrative. At the time, K. Halushko proposed ethnosocial and historicalphilosophical interpretation of the problem of the national grand-narrative. In his opinion, "nations, of course, exist only as ideas and identities in the imagination of people, but at the same time, they persistently influence their physical being, as well as the rest that exists in their imagination" (Halushko, 2013).

In order to create a unified grand-narrative of the Ukrainian nation, each citizen should realize his own involvement in its writing. In 2014, the Revolution of Dignity, which we have repeatedly addressed to in this study, once again proved the importance of civil liberties and human rights in the process of preserving and forming the spiritual and material foundation of Ukrainian statehood. Language is the basis for the formation of any narrative, and it is the one that must be realized by us as a tool for constructing a better social reality. Science has long moved away from defining a person, a subject of speech perception, as a passive observer. A person creates his 
reality with language through communicative action. The particularity of the behavior of Ukrainian citizens in the network requires a more thorough analysis because that becomes decisive on the path of the unified grand-narrative formation. The appeal to social media is driven by two factors:

1) in virtuality, language is the dominant phenomenon, here it constructs reality, establishes connections and destroys them;

2) connections formed by subjects in the process of communication are impossible without the use of language as an instrument of communicative action.

Thus, as Lesya Ukrainka wrote, language is our "only weapon" in the process of constructing our own grand-narrative. The main question facing all researchers of this issue is to what extent is society ready to implement the ideals of its own discourse for a better future?

A public opinion poll carried out by the Kyiv International Institute of Sociology at the beginning of 2015 once again confirmed how low the level of Ukrainians' trust in civil society institutions is and how high the indicator of the transfer of responsibility from their own Self to abstract factors remains. In particular, the church remained the leader of Ukrainians' trust - 58.8\%. On the other hand, public organizations and the patrol police should be the very clusters for whom democratic and humanistic values are an ideological prerogative, and a sense of responsibility towards Others should direct their personal activities - these two did not have such a level of trust $-34.5 \%$ and $20.7 \%$, respectively (Dovira..., 2020).

One of the reasons for this situation can also be considered the false foundations on which the judgments of Ukrainians are based about their role in the establishment of democracy and overcoming social "diseases" (e.g., corruption) that slow down this process. Thus, according to a 2006 poll, $43.4 \%$ of Ukrainians were hindered from engaging in social activities by the lack of free time (Sociological Survey, 2008), and 24\% of the population said that being a citizen for them means "the ability to feel cared for by the authorities, to have adequate social guarantees." (Sotsiolohichne..., 2020). In $2008,58.8 \%$ of the respondents did not need any social activity at all (Sotsiolohichne..., 2020). These data indicate that the situation of the existential crisis that the Ukrainian nation experienced after gaining independence was not completely overcome. Statistics here plays the role of another argument to emphasize moral instability, misunderstanding of the reality in which we live, and to make a philosophical analysis of it. 
The mood changed significantly after the winter of 2013-2014 when many Ukrainians declared their civil position through their Facebook profiles and showed their own indifference shaping the Euromaidan discourse and recreating it in actions outside the virtual environment. This formed a trend towards the creation of new public organizations, and the beginning of the anti-terrorist operation in the East of the country caused an increase in volunteering. In 2015, according to the State Statistics Service, the number of members registered with public organizations was more than 25 million people.

Orysia Lutsevych, an advisor to the Westminster Foundation in Ukraine, paid attention to the phenomenon that public organizations are creating today and called it NGO-cracy. At present, their leaders, who must play the role of an intermediary between the public and the state, that is, be evenly involved both in the public sphere of community life and in the political sphere, use their access to politicians and Western donors to influence public policy, limiting the needs of citizens (Lutsevych, 2020). 124 The mass media form the narrative of the identification of the activities of public organizations with the process of the civil society formation. The monopolization of discourse is underway, leaving volunteers, think-tanks in educational institutions and other associations initiated by citizens to improve the well-being of all outside the communicative activities of volunteers. The joint communicative and teleological actions of these subjects are capable of affirming humanistic and democratic values and freedom - the foundations of civil society.

The above situation can be explained today by the existence of three different modes of the signification of the symbolic world, which determine three levels of social discursive and ethical practices: (a) freedomauthenticity, which is immanent for the construction of the ideal and the policy of citizenship; (b) clientism-paternalism, which is characteristic of traditional social interactions; (c) nihilism-anarchy, which develops under the predominant influence of sublimated forms of thinking and behavior caused by the desire for pleasure due to dominance, including on the basis of resentiment, as a perverse option (Karas, 2016, 13-28).

In the end, the Ukrainian society does not develop in the direction of a unified model of social relations, therefore, the achievement of commonness in one activity or another is often impossible. This message can also become an argument in favor of the prevalence of the discursive and ethical practice of nihilism-anarchy in Ukrainian society. The reasons for this 
are several factors: first, the difference in worldviews between generations of people who were formed under the influence of the Soviet Union propaganda and was not able to overcome dependence on the system, and those whose consciousness was formed in the independent Ukrainian state or they managed to accept the values of the new society; secondly, for a long time in the media space, a discourse imposed from the outside developed, in which Ukrainian independence was interpreted as a simulacrum, which negatively affected public consciousness. Despite the fact that these people exist in the same space and time, their values and moral guidelines are on different planes. It is this very mental state that causes the crisis of social values, intensified by the surge of aggression in the east of Ukraine (Luchak, 2016, 24-29).

According to J. Habermas and N. Taleb, the economic and political crisis is not the cause of the crisis of identity, rather the crisis of morality and citizens causes it. Over the centuries of empires rule over Ukraine, the formation and dissemination of stable ethical imperatives were hindered by the narratives of other people's identities. Long-term searches for Self outside one's own cultural field, in other ideals and norms, leveled national identity and made them dependent on external authority both in material issues and in the ability to form and verify their own civic imperatives.

When a social system produces fewer problem-solving opportunities than is necessary for its own self-preservation, it becomes unstable, which causes a crisis. "Social systemic crises arise not because of random changes in the surrounding world, but through structurally determined systemic imperatives that are incompatible and cannot be brought into a single hierarchy" (Habermas, 2010, 10). These are the ethical imperatives of Soviet propaganda that still live in the minds of Ukrainians, and the imperatives that are focused on humanistic European values, but have not yet formed their own national discourse for their implementation. Communist ideas and corruption have reincarnated for the younger generation into a semblance of customs and traditions: they have become universal forms of interaction and social normativity, a ghost of the collective unconscious, which rests on the authority of experience. It is difficult to forget the jointly acquired level of moral consciousness due to the continuation of traditions. In other words, the common life world of the Ukrainian people is saturated with simulacra of values and liberal ideas, but not their real symbols, on the basis of which civil society should be built. The discourse of power remains closed to the communicative action that must 
come from public activists, and their discourse, unfortunately, does not have sufficient influence to form a power narrative. Europeanization, as a metanarrative, means for Ukraine to identify itself with the European community, in fact, because of common values and norms, as well as taking responsibility for the common European good. European identity is a collective consciousness that arises from identifying oneself with the deliberately accepted traditions of a certain ethical and cultural community (Luchak, 2015, 326-329).

"Social systems change their normative parameters depending on the state of productive forces and the degree of system autonomy, however, variations in normative parameters are limited by the logic of the development of pictures of the world, on which the imperatives of system integration have no influence" (Habermas, 2010, 20). Pictures of the world represent the life world of a separate society, consolidate the interpretative work done by previous generations in the field of interpreting the experience of dealing with reality, reflect the background knowledge (Hintergrundwissen) of communities and coordinate the connection of diverse landmarks and actions. The structures of intersubjectivity that arise thanks to language are the way of changing the pictures of the world and normative parameters. The life world for J. Habermas is "absolutely known knowledge" which has intersubjective significance and makes it possible for unhindered communication between members of the linguistic community.

The mechanisms that cause a change in the picture of the world and its normative structure are completely independent of the logic of social development, and therefore there is no guarantee that the axiology of the community will also change due to changes in economic and political realities. According to J. Habermas, social evolution is rather carried out within the framework of the logic of the life world, the structures of which are determined by intersubjectivity, created thanks to language, and are based on claims of significance that can be criticized (Habermas, 2010, 29). Changing regulatory structures follows the logic of growing theoretical and practical understanding.

Precisely because of the search for a vision and understanding of the future world in the early 21 st century that scientific discourse has been significantly enriched with theories of Internet democracy and new visions of democracy as a social phenomenon in the information era. Three theories are most advanced today. The first is the liberal individualistic model, according to which the characteristics of the Internet make it an environment 
conducive to expressing the personal interests of citizens, and form access to a large amount of open political information, make it possible to express one's opinion directly in front of one's own elected officials. This model is at the forefront of government policy-making, e-democracy commercial initiatives, and much social science research. However, it is not the only one. The communitarian model has significant support from public media activists in direct opposition to the individualistic ethos of the first model. The communitarian stance emphasizes the ability of Internet communities and networks to maintain and foster a spirit of unity and shared values.

In contrast to the first two positions, the deliberative model is more visible in academic and social circles, where the idea of e-democracy is firmly approved. This model positions the Internet as a means for expanding the sphere of openness of public deliberation, where a rational public opinion is formed and realizes itself, which can be reckoned with by representatives of state institutions that make political decisions. Thus, this third model claims to promote "strong" democracy, in contrast to the first two. Critics and theorists of deliberative democracy agree that the Internet will potentially facilitate the existence of the sphere of openness, but there are a number of sociocultural obstacles that stand in the way of unlocking this potential.

Conclusions. One of the main questions that are raised in modern discussions about the possible consequences of introducing digital technologies into political processes are doubts whether their inclusion in the political sphere will really bring the desired changes in the democratic structures of interaction between citizens and the state. Will this not create a system in the system and the state will lose its human face forever? In Plato's ideal state, power belonged to judicious philosophers, who were the only ones who understood the true meaning of good. Perhaps in the coming decades, artificial intelligence, which today manages unmanned vehicles and does surgeries on the human body, is able to independently learn and improve, will be able to eliminate the human factor and control society precisely through networks. According to N. Taleb, states and order are only an illusion of a world where the Black Swan can destroy everything. But the world will not be recognizable to us without the illusion of order. 


\section{Джерела та література:}

1. Андерсон Р. Д. (2003). Дискурсивне походження диктатури і демократії. Універсум. 2003. № 7-10. https://goo.gl/zk8FdF (дата звернення: 07.09.2020).

2. Галушко К.Ю. Сучасний український гранд-наратив: підходи, концепції, реалізація. Український історичний журнал. 2013. №1. C. 5-6.

3. Горенко О.М. Український метанартив в епоху пропаганди. Український історичний журнал. 2014. №2. URL: https://goo.gl/ ZkmwPW (дата звернення: 21.08.2020).

4. Довіра до соціальних інституцій та груп. URL: https://goo.gl/ nmafJr (дата звернення: 07.09.2020).

5. Карась А. Ф. Свобода і відповідальність як проблема самоздійснення особи. Вісник Львівського університету. Серія філософські науки. 2016. № 18. С. 13-28.

6. Лучак А.-М.М. Деліберативна демократія як форма правлін128 ня в інформаційному суспільстві. Філософія як культурна політика - сучасності: тези доповідей III всеукр. наук. конф. (м. Острог, 14-15 жовт. 2015 р.). Острог: Вид-во Нац. ун-ту «Острозька академія». 2015. C. 62-65.

7. Лучак А.-М.М. Електронне врядування як шлях утвердження цінностей деліберативної демократії. Філософія діалогу й порозуміння в побудові європейської і світової спільнот: тези міжнар. конф. (м. Львів, 22-24 черв. 2016 р.). Львів: ВЦ філософ. ф-ту ЛНУ ім. Івана Франка, 2016. С. 147-149.

8. Лучак А.-М.М. Свобода самовизначення як умова конструювання європейської ідентичності українця. Наукові записки Національного університету “Острозька академія”. Серія “Культурологія”. 2015. Вип. 16. С. 326-329.

9. Масуда Й. Комп'ютопія. Філософська і соціологічна думка. Київ, 1993. С. 36-50.

10. Талеб, Н. Н. Антихрупкость: как извлечь вигоду из хаоса / пер. с англ. Н. Караев. Москва, 2016. 768 с.

11. Уявлення про те, що означає бути громадянином. Соціологічне опитування Центру Разумкова. URL: https://goo.gl/Y75PqH (дата звернення: 12.08.2020). 
12. Фукуяма Ф. Суспільство в Україні може стати натхненням для інших країн. Paltforma. 2016. URL: https:/goo.gl/kjxT9U (дата звернення: 12.08.2020).

13. Хабермас Ю. Вовлечение другого. Очерки политической теории. Санкт-Петербург, 2001. 417 с.

14. Хабермас Ю. Проблема легитимации позднего капитализма. Москва, 2010. 264 с.

15. Чому Ви не залучені до громадської діяльності? Соціологічне опитування Центру Разумкова. 2008. URL: https://goo.gl/Uh3WH8 (дата звернення: 21.08.2020).

16. Що заважає Вашій громадській активності? Соціологічне опитування Центру Разумкова. 2008. URL: https://goo.gl/1cu2D8 (дата звернення: 21.08.2020).

17. Declaration of Principles. Building the Information Society: a global challenge in the new Millennium. URL: https://goo.gl/p17fdB (дата звернення: 21.08.2020).

18. Habermas J. The theory of communicative action. Boston, 1984. $457 \mathrm{p}$.

19. Luchak A.-M. Network and Communicative Transformation of Civil Society: Ukrainian Context. Virtus. 2016. №10. P. 24-29.

20. Lutsevych O. How to Finish a Revolution: Civil Society and Democracy in Georgia, Moldova and Ukraine. Chatam House. URL: https://goo.gl/AEpQLc (дата звернення: 11.07.2020).

\section{References:}

1. Anderson R. D. (2003). Dyskursyvne pokhodzhennia dyktatury i demokratii. Universum. 2003. № 7-10. https://goo.gl/zk8FdF (data zvernennia: 07.09.2020).

2. Halushko K.Iu. Suchasnyi ukrainskyi grand-naratyv: pidkhody, kontseptsii, realizatsiia. Ukrainskyi istorychnyi zhurnal. 2013. №1. C. 5-6.

3. Horenko O.M. Ukrainskyi metanartyv $\mathrm{v}$ epokhu propagandy. Ukrainskyi istorychnyi zhurnal. 2014. №2. URL: https://goo.gl/ZkmwPW (data zvernennia: 21.08.2020).

4. Dovira do sotsialnykh instytutsii ta hrup. URL: https://goo.gl/ nmafJr (data zvernennia: 07.09.2020).

5. Karas A. F. Svoboda i vidpovidalnist yak problema samozdiisnennia osoby. Visnyk Lvivskoho universytetu. Seriia filosofski nauky. 2016. № 18. S. 13-28. 
6. Luchak A.-M.M. Deliberatyvna demokratiia yak forma pravlinnia $\mathrm{v}$ informatsiinomu suspilstvi. Filosofiia yak kulturna polityka suchasnosti: tezy dopovidei III vseukr. nauk. konf. (m. Ostroh, 14-15 zhovt. 2015 r.). Ostroh: Vyd-vo Nats. un-tu «Ostrozka akademiia». 2015. S. 62-65.

7. Luchak A.-M.M. Elektronne vriaduvannia yak shliakh utverdzhennia tsinnostei deliberatyvnoi demokratii. Filosofiia dialohu y porozuminnia v pobudovi yevropeiskoi i svitovoi spilnot: tezy mizhnar. konf. (m. Lviv, 22-24 cherv. 2016 r.). Lviv: VTs filosof. f-tu LNU im. Ivana Franka, 2016. S. 147-149.

8. Luchak A.-M.M. Svoboda samovyznachennia yak umova konstruiuvannia yevropeiskoi identychnosti ukraintsia. Naukovi zapysky Natsionalnoho universytetu "Ostrozka akademiia". Seriia "Kulturolohiia". 2015. Vyp. 16. S. 326-329.

9. Masuda Y. Kompiutopiia. Filosofska i sotsiolohichna dumka. Kyiv, 1993. S. 36-50.

10. Taleb, N. N. Antykhrupkost: kak yzvlech vyhodu yz khaosa / per. 130 s anhl. N. Karaev. Moskva, 2016. 768 s.

11. Uiavlennia pro te, shcho oznachaie buty hromadianynom. Sotsiolohichne opytuvannia Tsentru Razumkova. URL: https://goo.gl/Y75PqH (data zvernennia: 12.08.2020).

12. Fukuiama F. Suspilstvo v Ukraini mozhe staty natkhnenniam dlia inshykh krain. Paltforma. 2016. URL: https:/goo.gl/kjxT9U (data zvernennia: 12.08.2020).

13. Khabermas Yu. Vovlechenye druhoho. Ocherky polytycheskoi teoryy. Sankt-Peterburh, 2001. 417 s.

14. Khabermas Yu. Problema lehytymatsyy pozdneho kapytalyzma. Moskva, 2010. 264 c.

15. Chomu Vy ne zalucheni do hromadskoi diialnosti? Sotsiolohichne opytuvannia Tsentru Razumkova. 2008. URL: https://goo.gl/Uh3WH8 (data zvernennia: 21.08.2020).

16. Shcho zavazhaie Vashii hromadskii aktyvnosti? Sotsiolohichne opytuvannia Tsentru Razumkova. 2008. URL: https://goo.gl/1cu2D8 (data zvernennia: 21.08.2020).

17. Declaration of Principles. Building the Information Society: a global challenge in the new Millennium. URL: https://goo.gl/p17fdB (data zvernennia: 21.08.2020).

18. Habermas J. The theory of communicative action. Boston, 1984. $457 \mathrm{p}$. 
19. Luchak A.-M. Network and Communicative Transformation of Civil Society: Ukrainian Context. Virtus. 2016. №10. P. 24-29.

20. Lutsevych O. How to Finish a Revolution: Civil Society and Democracy in Georgia, Moldova and Ukraine. Chatam House. URL: https:// goo.gl/AEpQLc (data zvernennia: 11.07.2020). 